\title{
RISK BASED AUDIT OLEH SATUAN KERJA AUDIT INTERN PADA PT. BANK JAT
}

\author{
Devi Afifah Sukmawardhani Achmad ${ }^{1}$ \\ Email: devi.achmad@gmail.com
}

\begin{abstract}
Based on Indonesia Bank Regulation Number 11/25/PBI/2009 about changes to the regulations of Bank of Indonesia Number 5/8/PBI/2003 which requires commercial banks in Indonesia to apply risk management in banking activities. The regulation requires banks indirectly push the activity of the audit process by applying risk-based Internal Audit (Risk Based Audit). Risk Based Audit is the audit that focused and prioritized in areas of high risk business segment. Implementation of Risk Based Auditing Standards refer to the Implementation of Internal Audit Function (SPFAIB) issued by Bank Indonesia and the Internal Audit Charter PT. Bank JAT. This reasearch aims to determine and evaluate the implementation of Risk Based Audit conducted by the Internal Audit Division (IAD) PT. Bank JAT is already in accordance with the standards of Bank Indonesia. Evaluation is conduct by distributing questionnaires to the Internal Audit Division (IAD) for the position, qualifications, work planning, risk assessment, and implementation of Risk Based Audit by the Internal Audit Division (IAD). Based on the evaluationl results of the implementation of Risk Based Audit in PT. Bank JAT, it can be concluded that the implementation has been in accordance with SPFAIB. Expected implementation of the Risk Based Audit is able to minimize the risk and incidence of irregularities that occurred in the activity of PT. Bank JAT.
\end{abstract}

Keywords: Risk Based Audit, Internal Audit Division (IAD)

\section{PENDAHULUAN}

Bank dalam melakukan fungsinya sebagai lembaga intermediasi keuangan harus kuat dan mampu mengikuti berbagai ketentuan praktik standart perbankan. Perbankan merupakan bisnis yang rentan akan risiko. Peningkatan kompleksitas operasi dan kegiatan akan berdampak pada peningkatan risiko bank. Untuk itu, diperlukan suatu cara baru untuk mengantisipasi dampak kerugian ataupun risiko yang akan dihadapi perbankkan.

Risk management atau menajemen risiko merupakan suatu instrumen yang penting untuk menyederhanakan kompleksitas yang dihadapi dalam operasional

\footnotetext{
${ }^{1}$ Corresponding Author: Fakultas Ekonomi Universitas Jember, Jl. Kalimantan No. 37 Jember 68121
} 
perbankkan. Manajemen risiko sendiri memiliki pengertian sebagai serangkaian prosedur serta metodologi yang digunakan untuk mengidentifikasi, mengukur, memantau, dan mengendalikan risiko yang timbul dari aktivitas usaha bank. Menurut Tampubolon $(2005,3)$ dalam bidang manajemen dan penyusunan strategi, risiko didefinisikan sebuah rentang (continuum) yang dapat bergerak ke arah ancaman dengan dampak negatif, yaitu tidak tercapai tujuan, atau kesempatan denagn dampak positif, yaitu tercapainya tujuan yang ditetapkan desertai berbagai tingkat kemungkinan terjadinya ancaman maupun peluang.

Dalam melakukan usahanya bank menghadapi berbagai risiko, baik risiko yang berasal dari luar bank maupun yang berasal dari dalam bank itu sendiri. Risiko yang berasal dari luar diantaranya disebabkan oleh perubahan dalam keadaan ekonomi, seperti kebijakan pemerintah atau sebagai akibat dari pengaruh perubahan perekonomiaan internasional. Sedangkan risiko yang berasal dari dalam bank antara lain adalah penyimpangan atau pelanggaran atas peraturan dan kebijakan yang berlaku serta praktik perbankan yang tidak sehat.

Penerapan manajemen risiko bank umum di Indonesia dilaksanakan berdasarkan Peraturan Bank Indonesia (PBI) Nomor 11/25/PBI/2009 tentang perubahan atas peraturan Bank Indonesia Nomor 5/8/PBI/2003 tentang penerapan manajemen risiko bagi bank umum yang mewajibkan untuk melakukan proses identifikasi, pengukuran, pemantauan, dan pengendalian risiko yang didukung oleh sistem informasi manajemen yang tepat waktu serta laporan yang akurat dan informatif mengenai kondisi keuangan bank, kinerja aktivitas fungsional dan eksposur risiko bank.

Setelah dikeluarkannya Peraturan Bank Indonesia Nomor 5/8/PBI/2003 tersebut secara tidak langsung menuntut industri perbankkan untuk merubah proses dan aktivitas auditnya dengan menerapkan Internal Audit berbasis risiko (Risk Based Audit). Menurut Dunil (2004, 19) audit berdasarkan risiko adalah audit yang difokuskan dan diprioritaskan pada risiko bisnis dan prosesnya serta pengendalian terhadap risiko yang dapat terjadi. Hal tersebut merubah cara pandang auditor intern bank yang dulu dianggap sebagai "watchdog”, yaitu selain sebagai pemeriksa, audit intern juga berfungsi sebagai partner auditee (manajemen).

Pengimplementasian Risk Based Audit sendiri memiliki beberapa tujuan diantaranya, selain mengurangi risiko bank, Risk Based Audit juga berfungsi untuk mengantisipasi timbulnya kerugian pada bank dengan cara mengantisipasi area-area yang berpotensi memiliki risiko tinggi sehingga dapat melindungi pihak bank dari kejadian yang tidak terduga.

Pelaksanaan Risk Based Audit menghasilkan suatu ranting yang menggambarkan tingkat pengelolaan risiko kantor cabang yang digunakan sebagai dasar untuk menilai kinerja kantor cabang tersebut. Penilaian oleh unit Satuan Kerja Audit Internal (SKAI) bank berdasarkan hasil pemeriksaan kantor cabang maupun kantor cabang pembantu yang dikaitkan dengan aspek pengendalian (internal control). Menurut Peraturan Bank Indonesia Nomor 5/8/PBI/2003 penilaian yang dilakukan oleh unit Satuan Kerja Audit Internal (SKAI) terhadap sistem pengendalian intern bank khususnya atas pelaksanaan Risk Based Audit, mempunyai kewajiban untuk memastikan bahwa:

1. Kepatuhan terhadap peraturan dan perundang-undangan yang berlaku serta kebijakan atau ketentuan internal bank 
2. Tersedianya informasi keuangan dan manajemen yang lengkap, akurat, tepat guna, dan tepat waktu

3. Efektifitas dan efesiensi dalam kegiatan operasional

4. Efektifitas budaya risiko (risk culture) pada organisasi bank secara menyeluruh.

Penerapan Risk Based Audit dapat bervariasi antara satu bank dengan bank lain sesuai dengan tujuan, kebijakan usaha, ukuran dan kompleksitas usaha serta kemampuan bank dalam hal keuangan, infrastruktur pendukung, maupun sumber daya manusia. Dalam rangka peningkatan kebutuhan akan praktek tata kelola yang sehat ini, maka peranan unit Satuan Kerja Audit Internal (SKAI) untuk menilai internal control merupakan fungsi yang harus dijalankan dengan efektif. Dengan terciptanya sistem pengendalian yang efektif dan efisien serta tata kelola perusahaan yang sehat (Good Corporate Governance), secara langsung dapat berpengaruh terhadap peningkatan kinerja perusahaan.

Penelitian mengenai Risk Based Audit ini penting dilakukan karena Risk Based Audit merupakan pendekatan audit baru yang memfokuskan diri pada manajemen risiko yang efektif dan memperbesar peran auditor internal dalam hal memitigasi risiko dalam melindungi bank dari risiko-risiko yang dapat mengancam kegiatan operasional bank. Dengan penelitian ini dapat diketahui sampai sejauh mana penerapan Risk Based Audit diterapkan oleh perusahaan sesuai dengan Peraturan Bank Indonesia yang baru serta Standart Pelaksanaan Fungsi Audit Intern Bank.

Penelitian mengenai Risk Based Audit ini pernah dilakukan oleh Iwan Hermawan (2006). Penelitian tersebut mengenai Evaluasi Proses Penerapan Risk Based Internal Audit Dalam Internal Audit Perbankan (Study Kasus Pada Bank Bukopin Cabang Surabaya Gubeng). Hasil dari penelitian tersebut disimpulkan bahwa secara umum risk based internal audit yang dilakukan di Bank Bukopin telah sesuai dengan prinsip-prinsip maupun definisi serta peran baru internal auditor. Namun, ada beberapa kelemahan yang perlu mendapat perhatian khusus dalam proses penerapan risk based internal audit seperti terkait dengan proses penilaian risk maturity perusahaan, belum adanya standarisasi tools untuk menjalankan risk based internal audit di SKAI Cabang, serta belum memiliki pedoman audit berdasarkan risiko. Penelitian selanjutnya dilakukan oleh Jocelin (2010). Penelitian tersebut membahas tentang Efektivitas Penerapan Risk Based Internal Audit Dalam Meningkatkan Kualitas Manajemen Risiko (Studi Kasus Pada PT. X di Gresik). Hasil yang diperoleh dari penelitian ini, secara khusus untuk risiko terkait aktivitas pemasaran dan distribusi, adalah SPI telah menjalankan peran konsultannya secara cukup efektif melalui pemberian berbagai rekomendasi perbaikan kepada unit kerja. Namun, peran assurance belum dijalankan secara efektif sehingga berbagai kerugian dan risiko masih terjadi. Penerapan audit berbasis risiko secara keseluruhan pada dua risiko yang menjadi lingkup penelitian ini kurang optimal memberikan nilai tambah begi peningkatan kualitas manajemen risiko pada unit-unit kerja tersebut.

Berdasarkan latar belakang permasalahan diatas, maka rumusan masalah yang akan dikaji dalam penelitian ini, yaitu: Bagaimana pelaksanaan Risk Based Audit oleh Satuan Kerja Audit Internal (SKAI) pada PT. Bank JAT dibandingkan dengan teori Risk Based Audit? 


\section{LANDASAN TEORI DAN PENGEMBANGAN HIPOTESIS 2.1 Manajemen Risiko}

Proses pengelolaan terhadap jenis-jenis risiko perbankan sangat diperlukan. Peraturan Bank Indonesia tentang perubahan atas Peraturan Bank Indonesia Nomor 5/8/PBI/2003, bank-bank umum di Indonesia diwajibkan untuk mampu mengelola setiap aktivitas fungsionalnya kedalam suatu sistem yang terintegrasi dan mengelola risiko yang akurat dan komprehensif. Dalam Peraturan Bank Indonesia Nomor 11/25/PBI/2009 tersebut manajemen risiko didefinisikan sebagai serangkaian metodologi dan prosedur yang digunakan untuk mengidentifikasi, mengukur, memantau, dan mengendalikan risiko yang timbul dari kegiatan bank.

Menurut Idroes $(2008,5)$ manajemen risiko adalah sebuah metode logis dan sistematis dalam mengidentifikasi, mengkuantifikasi, menentukan sikap, menentukan solusi, serta melakukan pemantauan dan melaporkan risiko yang berlangsung pada setiap aktivitas dan proses.

Sukarman dalam Tampubolon $(2005,33)$ mendefinisikan manajemen risiko sebagai keseluruhan sistem pengelolaan dan pengendalian risiko yang dihadapi oleh bank yang terdiri dari seperangkat alat, teknik, proses manajemen (termasuk kewenangan dan sistem dan prosedur operasional) dan organisasi yang ditujukan untuk memelihara tingkat profitabilitas dan tingkat kesehatan bank yang telah ditetapkan dalam corporate plan atau rencana strategis bank lainnya sesuai dengan tingkat kesehatan bank yang berlaku.

Thornhill dalam Tampubolon $(2005,34)$ mendefinisikan manajemen risiko sebagai sebuah disiplin pengelolaan yang tujuannya adalah untuk melindungi aset dan laba sebuah organisasi dengan mengurangi potensi kerugian sebelum hal tersebut terjadi, dan pembiayaan melalui asuransi atau cara lain atas kemungkinan rugi besar karena bencana alam, keteledoran manusia, atau karena keputusan pengadilan.

\subsection{Risk Based Audit}

Menurut Dunil $(2004,18)$ audit berbasis risiko adalah audit yang difokuskan dan diprioritaskan pada risiko bisnis dan prosesnya serta pengendalian risiko yang dapat terjadi. Oleh karena itu audit berbasis risiko menetapkan fokus dan prioritas pemeriksaan berdasarkan risiko, dengan begitu area yang berisiko tinggi lebih difokuskan atau diprioritaskan. Apabila aspek dan area yang berisiko tinggi sudah terperiksa dengan frekuensi yang lebih sering, maka tingkat penyimpangan dapat dikendalikan dan diminimalkan.

Dalam implementasi Risk Based Audit pihak SKAI sejak awal dilibatkan sebagai participant dalam menyusun strategic plan bersama dengan pihak manajemen. Strategi plan disusun berdasarkan arah bisnis serta risikonya, klasifikasi risiko setiap satuan, aktivitas, produk, proses transaksi serta dipahaminya aspek bisnis yang berisiko tinggi, moderate dan yang berisiko rendah. SKAI juga melakukan pengawasan atas pelaksanaan manajemen risiko apakah telah dilakukan sesuai dengan ketentuan yang telah ditetapkan dalam strategic plan, sehingga SKAI mengetahui suatu persoalan secara real time. Rencana audit diarahkan, difokuskan, dan diprioritaskan berdasarkan scenario analysis yang ditarik dari strategic plan yang telah dibuat, sehingga assesment risiko oleh SKAI tidak hanya berdasarkan risk factor dari pengalaman audit (Dunil 2004, 26). Hal tersebut membawa perubahan pada proses audit pada bank yang dahulu dilakukan secara konvensional dan sekarang dilakukan berbasis risiko. 


\subsection{Risk Based Audit: Suatu Kebutuhan}

Prativi dan Octava (2013) melakukan penelitian mengenai Evaluasi Efektivitas Fungsi Satuan Pengawas Intern Dalam Melaksanakan Audit Internal Pada PT. Petrokimia Gresik. Dari hasil penelitian tersebut dapat disimpulkan bahwa pelaksanaan audit internal oleh SPI PT. Petrokimia gresik telah berjalan cukup efektif. Namun masih terdapat beberapa kelemahan dalam pengelolaan dan pelaksanaan kegiatan pemeriksaan terutama dalam hasil rencana kerja, pedoman pemeriksaan, pengembangan sumber daya manusia, dan perencanaan pemeriksaan.

Harymawan (2006) melakukan penelitian mengenai Evaluasi Proses Penerapan Risk Based Internal Audit Dalam Internal Audit Perbankan (Study Kasus Pada Bank Bukopin Cabang Surabaya Gubeng). Kesimpulan dari penelitian tersebut disimpulkan bahwa secara umum risk based internal audit yang dilakukan di Bank Bukopin telah sesuai dengan prinsip-prinsip maupun definisi serta peran baru internal auditor. Namun ada beberapa kelemahan yang perlu mendapat perhatian khusus dalam proses penerapan risk based internal audit seperti terkait dengan proses penilaian risk maturity perusahaan, belum adanya standarisasi tools untuk menjalankan risk based internal audit di SKAI Cabang, serta belum memiliki pedoman audit berdasarkan risiko.

Jocelin (2010) melakukan penelitian tentang Efektivitas Penerapan Risk Based Internal Audit Dalam Meningkatkan Kualitas Manajemen Risiko (Studi Kasus Pada PT. X di Gresik). Hasil yang diperoleh dari penelitian ini, secara khusus untuk risiko terkait aktivitas pemasaran dan distribusi, adalah SPI telah menjalankan peran konsultannya secara cukup efektif melalui pemberian berbagai rekomendasi perbaikan kepada unit kerja. Namun, peran assurance belum dijalankan secara efektif sehingga berbagai kerugian dan risiko masih terjadi. Penerapan audit berbasis risiko secara keseluruhan pada dua risiko yang menjadi lingkup penelitian ini kurang optimal memberikan nilai tambah begi peningkatan kualitas manajemen risiko pada unit-unit kerja tersebut.

\section{METODE PENELITIAN}

\subsection{Jenis Penelitian}

Pendekatan penelitian yang digunakan merupakan pendekatan deskriptif kualitatif metode kasus yang menurut Yin $(2003,1)$ secara umum merupakan strategi yang lebih cocok bila pokok pertanyaan suatu penelitian berkenaan dengan how dan why. Pendekatan kualitatif deskriptif yaitu suatu pendekatan yang menggunakan data, menggambarkan, dan menjelaskan secara sistematis, akrual, dan akurat mengenai fakta-fakta, sifat-sifat, serta hubungan antar fenomena yang diselidiki. Pendekatan deskriptif kualitatif bertujuan memberikan gambaran atau uraian atas penelitian yang dilakukan serta mengetahui penjelasan secara terperinci dan mendalam mengenai obyek studi penelitian.

\subsection{Responden}

Responden dalam penelitian ini adalah Auditor Internal pada perusahaan ini disebut dengan Satuan Kerja Audit Intern (SKAI). Jumlah anggota SKAI PT. Bank JAT sebanyak 34 orang. Berkaitan dengan hal tersebut, maka perlu dilakukan proses pengumpulan, pengolahan dan penganalisisan data berdasarkan landasan teori yang telah disusun, setelah itu membandingkannya dengan kondisi yang ada dalam pelaksanaan internal audit oleh Divisi SKAI pada PT. Bank JAT untuk kemudian 
dibuat sebuah kesimpulan. Peneliti menyusun suatu landasan teori dan mengumpulkan data yang berkaitan dengan pelaksanaan Risk Based Audit pada Divisi SKAI PT. Bank JAT:

1. Pengelolaan Divisi Satuan Kerja Audit Intern (SKAI) PT. Bank JAT

2. Pelaksanaan Risk Based Audit dalam pelaksanaan internal audit oleh Satuan

Kerja Audit Intern (SKAI) pada PT. Bank JAT

Analisis yang dilakukan peneliti dengan melakukan evaluasi pelaksanaan internal audit yang dilakukan oleh Satuan Kerja Audit Intern (SKAI) PT. PT. Bank JAT. Peneliti melakukan evaluasi atas dasar Standar Pelaksanaan Fungsi Audit Intern Bank (SPFAIB) yang dikeluarkan oleh Bank Indonesia dan konsep pelaksanaan Risk Based Audit berdasarkan teori yang relevan.

\section{HASIL DAN PEMBAHASAN}

\subsection{Risk Based Audit pada PT. Bank JAT}

Risk Based Audit diberlakukan oleh Satuan Kerja Audit Intern PT. Bank JAT pada tahun 2003. Pelaksanaan Risk Based Audit ini diterapkan setelah adanya perubahan Struktur Organisasi PT. Bank JAT yang membuat divisi baru yakni Divisi Pengawasan. Sejak 1 April 2011, menurut Struktur Organisasi yang baru Divisi Pengawasan berubah menjadi Divisi Audit Intern. Pengaplikasian Risk Based Audit pada PT. Bank JAT adalah untuk memperoleh efektivitas, efisiensi dan ekonomisasi dalam pelaksanaan audit. Audit dilakukan terhadap aktivitas - aktivitas yang dinilai berisiko tinggi. Risk Based Audit ini dipergunakan untuk mengetahui tingkat pengelolaan risiko atas aspek-aspek bisnis usaha dari kantor cabang yang digunakan sebagai dasar penilaian kinerja dari kantor cabang yang diperiksa tersebut.

Berdasarkan metode Risk Based Audit dalam menentukan cabang yang menjadi prioritas audit, dilakukan dengan mempertimbangkan:

a) Laporan TKS dan Profil Risiko cabang yang tersedia.

b) Agar lebih terarah pada potensi risiko yang menghambat tujuan bisnis cabang, dilakukan penilaian dan di renking tersendiri atas:

- Kinerja bisnis cabang dengan bobot $20 \%$

- Kualitas kredit dengan bobot $40 \%$

- Tingkat efisiensi dengan bobot $20 \%$

- Tingkat likuiditas dengan bobot $20 \%$ yang datanya diperoleh dari hasil monitoring / pemeriksaan pasif.

c) Judgement pertimbangan lain yang dapat dipertanggung jawabkan antara lain adalah Sistem Pengendalian Intern (tidak ada auditor cabang, cabang besar dan memiliki capem) serta pertimbangan debitur ekstrakomtabel.

Pada saat itu metode Risk Based Audit PT. Bank JAT masih memerlukan perubahan mengikuti perkembangan praktik perbankkan pada PT. Bank JAT dan berdasarkan pada tentuan serta ketetapan yang telah digariskan oleh pihak manajemen bank dan peraturan yang dikeluarkan oleh Bank Indonesia.

\subsection{Analisis dan Pembahasan}

\subsubsection{Kedudukan Satuan Kerja Audit Intern}

Struktur organisasi SKAI PT. Bank JAT disusun sedemikian rupa dengan tujuan untuk menjaga objektifitas dan independensi para auditor. SKAI PT. Bank JAT dalam melaksanakan fungsinya sebagai pihak yang independen dalam 
perusahaan untuk melakukan penilaian dan menyediakan informasi kepada pihak manajemen atas kecakupan dan efektifitas sistem pengendalian intern seluruh kantor cabang pada PT. Bank JAT.

Berdasarkan hasil penelitian (lampiran 1) tentang kedudukan SKAI dari 34 responden dapat diketahui bahwa, PT. Bank JAT memiliki struktur organisasi untuk SKAI dan pembagian tugas, wewenang serta tanggung jawab cukup jelas, 23 responden menjawab "ya" dan 11 responden menjawab "tidak". Dalam struktur organisasi, kedudukan SKAI berada dibawah Direktur Utama, seluruh responden menjawab "ya". SKAI dapat berkomunikasi langsung dengan Dewan Komisaris, 30 responden menjawab "ya" dan 4 responden menjawab "tidak". Pemberian informasi audit kepada Dewan Komisaris juga harus dilaporkan kepada Direktur utama dengan tembusan Direktur Kepatuhan, 32 responden menjawab "ya", sedangkan 2 responden menjawab "tidak".

Perbedaan jawaban kuesioner tersebut dikarenakan adanya auditor baru pada SKAI PT. Bank JAT yang masa kerjanya belum mencapai 1 tahun, sehingga mereka belum sepenuhnya mengetahui tentang tugas, wewenang dan tanggung jawab dari masing-masing auditor. Namun, hasil penelitian (lampiran 1) menunjukkan bahwa secara keseluruhan prosentase nilai dalam kedudukan SKAI PT. Bank JAT sebesar $90,00 \%$, nilai tersebut dikategorikan sangat baik.

\subsubsection{Kualifikasi Satuan Kerja Audit Intern}

SKAI harus memiliki auditor yang profesional agar fungsi audit intern dapat berjalan dengan efektif dan efisien. Berdasarkan hasil penelitian (lampiran 2) tentang kualifikasi SKAI PT. Bank JAT dari 34 responden dapat diketahui bahwa, dalam fungsi SKAI dilaksanakan oleh orang yang cukup berpengalaman, 22 responden menjawab "ya", sedangkan 12 responden menjawab "tidak". SKAI dapat dijamin independensinya, 31 responden menjawab "ya" sedangkan 3 responden menjawab "tidak". Dalam uraian tugas dan tanggung jawab setiap auditor cukup jelas serta diimplementasikan dengan baik, 30 responden menjawab "ya" dan 4 responden menjawab "tidak". Untuk menjadi auditor ditentukan jenjang pendidikan tertentu, 32 responden menjawab "ya" dan 2 responden menjawab "tidak". SKAI memiliki auditor yang telah bersertifikat auditor internal. Dalam hal ini 18 responden menjawab "ya" sedangkan 16 menjawab "tidak". SKAI diberi kesempatan untuk melanjutkan pendidikan dan pelatihan untuk meningkatkan mutu dan kualitas pekerjaannya, 33 responden menjawab "ya", seorang responden menjawab "tidak".

Berdasarkan hasil penelitian terdapat perbedaan jawaban dari tiap pertanyaan, hal tersebut disebabkan perbedaan masa kerja serta pengalaman dari masing-masing auditor. Auditor baru juga hanya beberapa kali melakukan audit. Mereka juga belum mengikuti semua pelatihan yang diadakan oleh PT. Bank JAT karena beberapa pelatihan hanya diikuti oleh auditor tertentu saja yang ditunjuk untuk mengikuti pelatihan tersebut, seperti audit fraund/investigasi serta cara pembuatan BAP yang efektif yang diikuti oleh 8 orang. Namun secara keseluruhan dari hasil penelitian tentang kualifikasi SKAI dapat dikategorikan baik dengan nilai prosentase sebesar $81,37 \%$. 


\subsubsection{Perencanaa Kerja SKAI}

SKAI dalam melakukan pengawasan dan pemeriksaannya harus didasarkan pada perencanaan. Rencana kerja audit yang dibuat setiap akhir tahun tersebut dengan tujuan dipakai sebagai pedoman dalam melakukan pemeriksaan agar pemeriksaan dapat dilakukan secara efektif, terarah dan terkoordinasi secara baik sehingga sistem dan strategi yang ditetapkan sesuai dengan tujuan dan sasaran perusahaan. Rencana kerja SKAI PT. Bank JAT secara garis besar berisikan hal-hal mengenai rencana pelaksanaan pemeriksaan SKAI terhadap kantor cabang, rencana peningkatan kualitas dan kuantitas Sumber Daya manusia, serta rencana biaya dan pembelian sarana kerja untuk memperlancar SKAI dalam melakukan pemeriksaan.

Berdasarkan hasil penelitian (lampiran 3) tentang perencanaan kerja SKAI dari 34 responden dapat diketahui bahwa, SKAI telah mempunyai rencana audit untuk pemeriksaan selama satu tahun. Rencana audit yang telah ditetapkan sesuai dengan Audit Internal Charter serta tujuan bank, 31 responden menjawab "ya", 3 responden menjawab "tidak". Rencana kerja tersebut dibuat oleh kepala SKAI, 16 responden menjawab "ya", 18 responden menjawab "tidak". Rencana kerja selama satu tahun tersebut telah mendapat persetujuan Direktur Utama dan Dewan Komisaris. Dalam penyusunan rencana audit terhadap kantor cabang selama satu tahun ke depan diprioritaskan pada kantor cabang yang memiliki area yang berisiko tinggi. Dalam rencana tersebut ditentukan jadwal audit, susunan tim audit dan anggaaran biaya dalam melakukan pemeriksaan, 30 responden menjawab "ya", 5 responden menjawab "tidak".

Perbedaan jawaban kuesioner tersebut karena tidak semua auditor ikut dalam penyusunan perencanaan kerja SKAI PT. Bank JAT. Penyusunan perencanaan kerja tersebut dilakukan oleh Pimpinan Sub Divisi Operasional dan Financial Audit dibantu oleh Junior Auditor, Auditor, dan Senior auditor. Kepala SKAI bertanggung jawab atas pembuatan rencana kerja tersebut agar dapat dipakai sebagai pedoman dalam melaksanakan tugas bagi satuan kerja yang dipimpinnya.

Dalam tahap perencanaan kerja, SKAI PT. Bank JAT telah menyusun perencanaan kerja selama satu tahun tersebut dengan baik sesuai dengan SPFAIB. Hasil penelitian (lampiran 3) menunjukkan bahwa prosentase nilai dalam perencanaan kerja SKAI PT. Bank JAT sebesar 87,75\%, nilai tersebut dikategorikan baik.

\subsubsection{Risk Assesment oleh Satuan Kerja Audit Intern (SKAI)}

Proses risk assesment merupakan tahapan penting dalam pelaksanaan Risk Based Audit. Tahapan risk assesment terdiri dari proses mengidentifikasi, mengukur, dan menentukan prioritas audit yang dilakukan terhadap aktivitas- aktivitas yang dinilai berisiko tinggi.

Berdasarkan hasil penelitian (lampiran 4) tentang pelaksanaan risk assessment oleh SKAI dari 34 responden dapat diketahui bahwa, SKAI PT. Bank JAT selalu melakukan risk assessment sebelum melakukan audit. Hasil risk assessment diotorisasi oleh pengawas dan ketua tim, 28 responden menjawab "ya" dan 6 responden menjawab "tidak". SKAI menentukan sasaran dan tujuan organisasi sebelum menaksir risiko. Selanjutnya SKAI menaksir risiko tersebut dengan melakukan proses identifikasi, mengukur serta menetapkan prioritas risiko, 30 responden menjawab "ya" dan 4 responden menjawab "tidak". SKAI mempunyai matriks penilaian risiko, 25 responden menjawab "ya" dan 9 responden menjawab 
“tidak". Dalam hal SKAI menetapkan kontrol terhadap risiko tersebut, 30 responden menjawab "ya" dan 4 responden menjawab "tidak".

Perbedaan jawaban kuesioner tersebut karena risk assesment dilakukan masih berdasarkan adjustment profesional dari auditor. Risk assesment yang merupakan subjektivitas auditor ini berdampak pada ketepatan hasil risk assesment. Hasil risk assesment yang dilakukan bergantung pada tingkat kemahiran, pengalaman, pengetahuan, dan pemahaman auditor yang memadai atas risiko yang ada pada kantor cabang. Akibat banyaknyaa karyawan yang memasuki masa purna tugas khususnya auditor pada SKAI PT. PT. Bank JAT berdampak pada transfer knowledge yang mengalami penurunan kualitas. Hal tersebut berpengaruh terhadap hasil risk assesment yang dilakukan oleh SKAI PT. Bank JAT.

Dalam tahap risk assessment, SKAI PT. Bank JAT telah melakukan penilaian dengan cukup baik. Hal ini dapat terlihat dari jawaban kuesioner pada proses risk assessment. Hasil penelitian (lampiran 4) menunjukkan bahwa prosentase nilai dalam risk assessment PT. Bank JAT sebesar $88,73 \%$, nilai tersebut dikategorikan baik.

SKAI PT. Bank JAT melakukan penilaian dan ranking tersendiri atas 4 faktor penilaian untuk kantor cabang yaitu: kinerja bisnis cabang, kualitas kredit, tingkat efisiensi, dan tingkat likuiditas, yang datanya diperoleh dari hasil monitoring / pemeriksaan pasif. SKAI membagi risiko menjadi 3 yaitu:

1. Risiko Rendah (Low). Risiko ini memiliki rasio total rangking antar 0\% $30,99 \%$

2. Risiko Sedang (Moderate). Risiko ini memiliki rasio total rangking antar $31,00 \%-70,99 \%$

3. Risiko Tinggi (High). Risiko ini memiliki rasio total rangking antar $71,00 \%$ $-100 \%$

Dari perhitungan total ranking tersebut akan diperoleh penentuan ranking risiko kantor cabang, dimana kantor cabang yang memiliki ranking terbawah merupakan cabang yang paling berisiko (risiko tinggi) sedangkan cabang yang memiliki ranking teratas merupakan cabang yang tidak berisiko (risiko rendah)

SKAI PT. Bank JAT belum menerapkan pembagian peringkat risiko bagi Bank Umum Konvensional menurut Peraturan Bank Indonesia yang baru yang mana risiko tersebut dikategorikan menjadi 5 (lima) peringkat, yaitu 1 (Low), 2 (Low to Moderate), 3 (Moderate), 4 (Moderate to High), dan 5 (High).

SKAI melengkapi risk faktor dari SKMR agar pelaksanaan risk assessment dapat mencapai tujuan yang telah ditentukan. Hal tersebut dilakukan karena SKMR adalah pemilik dan penanggung jawab atas manajemen risiko pada aktivitas usaha perbankkan pada PT. Bank JAT.

\subsection{Pelaksanaan Risk Based Audit}

\subsubsection{Persiapan dan Penyusunan Program Audit}

Pelaksanaan audit harus dipersiapkan dengan baik agar tujuan dan mutu audit dapat dicapai dengan cara efisien. Persiapan dan penyusunan program audit sebelum pelaksanaan pemeriksaan oleh SKAI PT. Bank JAT berfungsi untuk memfasilitasi pencapaian tujuan yang telah ditetapkan.

Berdasarkan hasil penelitian (lampiran 5) tahap persiapan dan penyusunan audit dari 34 responden dapat diketahu bahwa, persiapan audit dilakukan dengan baik oleh SKAI. Dalam melakukan persiapan audit, SKAI membuat surat penugasan, surat pemberitahuan audit untuk auditee serta melakukan proses penelitian 
pendahuluan sebelum melaksanakan audit. Setelah melakukan persiapan audit, auditor membuat audit program audit, 33 menjawab "ya", dan 1 orang menjawab "tidak". Program audit selalu direview oleh auditor, 26 responden menjawab "ya" sedangkan 8 responden menjawab "tidak". Dalam melakukan perubahan program audit harus mendapat persetujuan dahulu dari ketua tim audit. Hal ini dapat dilihat dari jawaban kuesioner, seluruh responden menjawab "ya" untuk pertanyaan tersebut.

Dalam tahap persiapan dan penyusunan program audit, SKAI PT. Bank JAT telah dilakukan dengan baik sesuai dengan SPFAIB. Hasil penelitian (lampiran 5) menunjukkan bahwa prosentase nilai pelaksanaan risk based audit PT. Bank JAT pada tahap persiapan dan penyusunan program sebesar 96,64 \%, nilai tersebut dikategorikan sangat baik. Perbedaan jawaban kuesioner tersebut karena sebagian auditor menganggap bahwa pada penyusunan program audit tersebut telah sesuai dengan kondisi kantor cabang yang diperiksa sehingga tidak perlu dilakukan perubahan atas program audit tersebut. Program audit tersebut dapat diubah sesuai dengan kebutuhan selama audit berlangsung.

\subsubsection{Pelaksanaan Penugasan Audit}

Pelaksanaan audit oleh SKAI PT. Bank JAT meliputi kegiatan mengumpulkan, menganalisis, menginterpretasikan dan mendokumentasikan buktibukti audit serta informasi lain yang dibutuhkan, sesuai dengan prosedur yang digariskan dalam program audit untuk mendukung hasil audit.

Berdasarkan hasil penelitian (lampiran 6) pada tahap pelaksanaan penugasan audit, dari 34 responden dapat diketahui bahwa, audit internal yang dilaksanakan oleh SKAI PT. Bank JAT seluruhnya berdasarkan program audit. Untuk bukti dan informasi yang dikumpulkan dalam pemeriksaan cukup, kompeten, dan relevan serta dilakukan evaluasi dengan baik, 32 responden menjawab "ya" dan 2 responden menjawab "tidak". Metode dan teknik sampling yang ditetapkan sesuai dengan keadaan pada saat pemeriksaan, seluruh responden menjawab "ya". Dalam setiap tahap pelaksanaan audit dilakukan supervisi, 32 responden menjawab "ya", 2 responden menjawab "tidak". Kertas kerja audit didokumentasikan oleh auditor dengan baik. Hal ini dibuktikan dengan seluruh responden menjawab "ya". Auditor juga membahas hasil auditnya dengan auditee, seluruh responden menjawab "ya". Adanya perbedaan jawaban kuesioner pada pelaksanaan penugasan audit tersebut dikarenakan beberapa auditor yang masih baru belum sepenuhnya berpengalaman dalam menggunakan pertimbangan profesionalnya untuk menentukan jumlah dan jenis bukti audit yang dibutuhkan dalam pemeriksaan.

Pelaksanaan penugasan audit oleh SKAI PT. Bank JAT secara garis besar telah dilaksanakan dengan baik sesuai dengan SPFAIB. Hasil penelitian (lampiran 6) menunjukkan bahwa prosentase nilai pelaksanaan risk based audit PT. Bank JAT pada tahap pelaksanaan penugasan audit sebesar $97,48 \%$, nilai tersebut dikategorikan sangat baik.

Dalam SKAI PT. Bank JAT juga terdapat pelaksanaan penugasan khusus. Pelaksanaan penugasan khusus tersebut dilakukan apabila terdapat indikasi adanya penyelewengan dan penyimpangan yang terjadi pada kantor cabang dan diperintahkan oleh Direktur Utama untuk dilakukan pemeriksaan lebih lanjut oleh SKAI. Selanjutnya disusun progran audit yang difokuskan pada penyelewengan dan penyimpangan yang terjadi. Jumlah auditor yang ditugaskan disesuaikan dengan 
obyek yang diperiksa. Penugasan berdasarkan kemampuan dilakukan agar pelaksanaan pemeriksaan khusus dapat berjalan lebih efektif dan efisien. Hal tersebut dilakukan agar laporan hasil pemeriksaan khusus secepatnya dapat disampaikan kepada Direktur Utama dan Manajemen untuk segera ditindaklanjuti.

\subsubsection{Pelaporan Hasil Audit}

Pelaporan hasil audit dilakukan sebagai bukti pertanggungjawaban SKAI PT. Bank JAT atas pelaksanaan pekerjaan lapangan untuk memeriksa kantor cabang. Auditor berkewajiban membuat laporan hasil audit secara tertulis yang harus memenuhi standar pelaporan, memuat kelengkapan materi, dan melalui proses penyusunan yang baik.

Berdasarkan hasil penelitian (lampiran 7) pada tahap pelaporan hasil audit dari 34 responden dapat diketahui bahwa, laporan hasil audit diterbitkan segera setelah audit intern dilaksanakan dan selalu tepat waktu, 29 responden menjawab "ya" dan 5 responden menjawab "tidak". Laporan hasil audit yang disajikan bersifat obyektif, singkat, jelas dan tepat sasaran, 32 responden menjawab "ya" sedangkan 2 responden menjawab "tidak". Materi laporan hasil audit cukup lengkap dan jelas sesuai dengan pedoman audit, 30 responden menjawab "ya" dan 4 responden menjawab "tidak". Laporan hasil audit selalu diberikan rekomendasiuntuk auditee Saran dan rekomendasi yang diberikan mendapat tanggapan atau tundak lanjut yang cepat dari auditee, 28 responden menjawab "ya" sedangkan 6 responden menjawab "tidak". Untuk Laporan hasil audit selalu disampaikan kepada Direktur Utama dan Dewan Komisaris dengan tembusan Direktur Kepatuhan serta dilaporkan juga kepada Bank Indonesia. Adanya perbedaan jawaban kuesioner pada tahap pelaporan tersebut, disebabkan karena selama proses audit terdapat adanya temuan audit yang membutuhkan pemeriksaan lebih mendalam atau pemeriksaan khusus oleh auditor, akibatnya jadwal pemeriksaan tersebut berubah sehingga menyebabkan laporan hasil audit juga ikut tertunda. Rekomendasi yang diberikan oleh auditor tidak dilakukan dengan cepat oleh beberapa auditee karena rekomendasi tersebut dinilai oleh auditee kurang sesuai dengan kondisi kantor cabang pada saat itu.

Berdasarkan hasil penelitian (lampiran 7) menunjukkan bahwa secara keseluruhan prosentase nilai dalam tahap pelaporan hasil audit SKAI PT. Bank JAT sebesar 92,86\%, nilai tersebut dikategorikan sangat baik dan sesuai dengan SPFAIB.

Pada PT. Bank JAT, selain Laporan Hasil Audit (LHA), Auditor Intern juga membuat membuat sebuah eksekutif sumery yaitu ringkasan laporan untuk Direksi (Resume Hasil Audit). Hal ini dikarena Direksi tidak mempunyai cukup waktu untuk membaca seluruh Laporan Hasil Audit. Isi dari laporan eksekutif sumery juga ada di dalam LHA, namun diringkas sedemikian rupa sehingga yang ada di dalam laporan eksekutif sumery itu yang pertama adalah kinerja bisnis cabang, sedangkan yang kedua adalah temuan- temuan yang dianggap penting baik dari aktivitas operasional dan jasa, kredit, dan teknologi sistem informasi.

Selain membuat laporan kepada Direktur Utama dan Dewan Komisaris, Auditor juga membuat laporan untuk Bank Indonesia. Laporan tersebut disampaikan Direktur Utama dan Dewan Komisaris kepada Bank Indonesia setiap semester. Laporan tersebut berupa rekap temuan pelaksanaan dan pokok-pokok hasil audit yang sudah diselesaikan dan belum diselesaikan oleh Auditor. 


\subsubsection{Tindak Lanjut Hasil Audit}

Hasil Pemeriksaan oleh SKAI dilaporkan kepada Dewan Komisaris, Direktur Utama, dan auditee. Hasil pemeriksaan tersebut selanjutnya dilakukan proses pemantauan atas tindak lanjut yang dilakukan oleh kantor cabang terhadap rekomendasi dan hasil temuan yang disampaikan auditor intern.

Berdasarkan hasil penelitian (lampiran 8) pada tahap tindak lanjut hasil audit dari 34 responden dapat diketahui bahwa, SKAI melakuakan evaluasi terhadap tanggapan yang diberikan manajemen, 33 responden menjawab "ya" dan seorang responden menjawab "tidak". SKAI melakukan evaluasi terhadap jangka waktu yang dibutuhkan oleh manajemen untuk menanggapi hasil observasi dan rekomendasi yang termuat dalam LHA, seluruh responden menjawab "ya". SKAI melakuakn pemantauan terhadap rekomendasi yang diberikan, 33 responden menjawab "ya" dan 1 responden menjawab "tidak". Saran dan rekomendasi yang diberikan oleh auditor dapat diterima dan dilaksanakan dengan baik oleh auditee, 28 responden menjawab "ya", 6 responden menjawab "tidak". Dalam proses tindak lanjut tidak terdapat kelemahan yang signifikan terhadap hasil tindak lanjut audit, 26 responden menjawab "ya", 8 responden menjawab "tidak". SKAI memberikan laporan tertulis kepada Direktur Utama dan Dewan Komisaris bila auditee tidak melakukan tindak lanjut atas hasil observasi dan rekomendasi yang disampaikan, 20 responden menjawab "ya", 14 responden menjawab "tidak". Adanya perbedaan jawaban kuesioner tersebut karena pada saat pemantauan tidak lanjut terdapat rekomendasi yang tidak dilaksanakan oleh auditee dengan alasan bahwa rekomendasi yang diberikan oleh auditor sudah tidak sesuai dengan kondisi kantor cabang. Bila rekomendasi tidak sesuai maka auditor memberikan rekomendasi lagi yang sesuai dengan kondisi pada saat itu.

Setiap tiga bulan sekali SKAI PT. Bank JAT mengadakan rapat kaji ulang. Rapat kaji ulang tersebut merupakan forum terbuka dimana semuanya hadir dalam rapat kaji ulang tersebut, baik Dewan Komisaris, Direktur Utama, maupun Auditee. Melalui rapat kaji ulang Auditor menyampaikan apa saja temuan yang belum dilaksanakan dan diselesaikan oleh pihak Auditee.

Tindak Lanjut atas rekomendasi dan temuan SKAI tersebut jika tidak dilakukan penyelesaian oleh kantor cabang, maka SKAI melalui rapat kaji ulang memberikan laporan tertulis kepada Direktur Utama dan Dewan Komisaris. Selanjutnya Direktur Utama memanggil Pimpinan Cabang untuk mempertanggungjawabkan kesalahan dan memberi teguran kepada kantor cabang. Apabila terdapat penyimpangan yang dirasa cukup fatal (material), maka Direktur Utama menerbitkan surat penugasan khusus kepada SKAI untuk dilakukan pemeriksaan khusus. Hasil pemeriksaan khusus tersebut langsung dilaporkan ke Direktur Utama sebagai bentuk pertanggung jawaban SKAI untuk segera ditindak lanjuti manajemen.

Berdasarkan hasil penelitian (lampiran 8) menunjukkan bahwa pelaksanaan tahap tindak lanjut hasil audit SKAI PT. Bank JAT telah sesuai dengan SPFAIB dengan prosentase nilai sebesar $85,29 \%$, nilai tersebut dikategorikan baik. 


\section{KESIMPULAN, IMPLIKASI DAN KETERBATASAN}

Penelitian ini bertujuan untuk mengetahui dan mengevaluasi apakah pelaksanaan Risk Based Audit yang dilakukan oleh Satuan Kerja Audit Intern (SKAI) PT. Bank JAT sudah sesuai dengan standart yang ditetapkan oleh Bank Indonesia. Dari hasil penelitian atas pelaksanaan Risk Based Audit oleh SKAI PT. Bank JAT, peneliti secara garis besar dapat memberikan kesimpulan sebagai berikut:

1) Kedudukan SKAI pada struktur organisasi PT. Bank JAT sesuai dengan SPFAIB dan dikaregorikan sangat baik dengan nilai prosentase sebesar $90,00 \%$.

2) Kualifikasi SKAI pada PT. PT. Bank JAT dikategorikan baik dengan prosentase sebesar $81,37 \%$.

3) Pelaksanaan Risk Based Audit pada tahap perencanaan kerja SKAI sesuai dengan SPFAIB dan dikategorikan baik dengan nilai prosentase sebesar $87,75 \%$.

4) Pelaksanaan Risk Based Audit pada tahap risk assessment yang dilakukan oleh SKAI PT. Bank JAT dikategorikan baik dengan nilai prosentase sebesar $88,73 \%$.

5) Pelaksanaan Risk Based Audit pada tahap persiapan dan penyusunan program audit sesuai dengan SPFAIB dan dikategorikan sangat baik dengan nilai prosentase sebesar 96,64\%.

6) Pelaksanaan Risk Based Audit pada tahap pelaksanaan penugasan audit sesuai dengan SPFAIB dan dikategorikan sangat baik dengan nilai prosentase sebesar $97,48 \%$.

7) Pelaksanaan Risk Based Audit pada tahap laporan hasil audit sesuai dengan SPFAIB dan dikategorikan sangat baik dengan nilai prosentase sebesar $92,86 \%$.

8) Pelaksanaan Risk Based Audit pada tahap tindak lanjut atas laporan hasil audit audit sesuai dengan SPFAIB dan dikategorikan baik dengan nilai prosentase sebesar $85,29 \%$.

Saran yang dapat diberikan oleh peneliti terhadap pelaksanaan Risk Based Audit pada PT. Bank JAT adalah sebagai berikut:

1) PT. Bank JAT hendaknya menyusun pedoman pelaksanaan audit intern berbasis risiko bagi Auditor. Tujuannya adalah untuk menyempurnakan pelaksanaan risk based audit PT. Bank JAT, karena salah satunya adalah dapat mengurangi kelemahan dalam transfer knowledge dari auditor senior kepada junior maupun pemahaman auditee tentang pelaksanaan risk based audit pada PT. Bank JAT.

2) Untuk meningkatkan kemampuan dan kompetensi para Auditor dapat dilakukan dengan mengadakan penambahan intensitas pendidikan dan pelatihan yang sesuai dengan tugas-tugas SKAI. Disamping itu juga sebaiknya auditor mengikuti seminar-seminar, workshop untuk menambah wawasan bidang audit.

3) SKAI sebaiknya membuat standarisasi kriteria dan penggolongan jenis risiko yang ditetapkan dalam Surat Keputusan Direksi yang mengacu pada Peraturan Bank Indonesia yang baru. Selain untuk mendeteksi risiko sejak dini hal tersebut juga untuk menyamakan persepsi auditor dalam menilai serta menggolongkan jenis risiko pada tahap risk assesment selain menggunakan subjektivitas auditor sendiri. 
4) Pelaksanaan penugasan khusus dari Direktur Utama mengakibatkan target rencana yang telah disusun mengalami perubahan. Untuk itu perlu dilakukan penambahan jumlah personil yang disertai dengan peningkatan kualitas SDM agar pelaksanaan fungsi audit dapat berjalan lebih efektif dan efisien sesuai dengan yang direncanakan.

\section{DAFTAR PUSTAKA}

Akmal. 2006. Pemeriksaan Intern. Jakarta: PT Indeks

Bank Indonesia. 2009. Peraturan Bank Indonesia No. 11/25/DNDP/2009. Jakarta: Bank Indonesia

Bank Indonesia. 1999, Peraturan Bank Indonesia No. 1/6/PBI/1999. Jakarta: Bank Indonesia

Bank Indonesia. 2003. Peraturan Bank Indonesia No. 5/8/PBI/2003. Jakarta: Bank Indonesia

Djojosoedarso, Soeisno. 2003. Prinsip-prinsip Manajemen Risiko Asuransi. Jakarta: PT. Salemba Empat

Dunil, Z. 2004. Risk Based Audit: Dalam Pemeriksaan Bank Umum. Jakarta Indeks.

Harymawan, I. 2006. Evaluasi Proses Penerapan Risk Based Internal Audit Dalam Internal Audit Perbankan (Studi Kasus Pada Bank Bukopin Cabang Surabaya Gubeng), UNIVERSITAS AIRLANGGA.

Herawati, Shinta Dewi. Peran Risk Based Internal Audit Dalam Penerapan Good Corporate Governance. Jurnal Bisnis, Manajemen, dan Ekonomi, Vol.9, No. 8, Maret 2010, Hlm. 2165-2176, ISSN: 1693-8305.

Idroes, F. N. 2008. Manajemen Resiko Perbankan, edisi pertama, cetakan pertama. Penerbit: RajaGrafindo Persada, Jakarta.

Jocelin. 2010. Efektivitas Penerapan Risk-Based Internal Audit Dalam Meningkatkan Kualitas Manajemen Risiko (Studi Kasus Pada PT" X" Di Gresik), UNIVERSITAS AIRLANGGA.

Prativi, O., dan R. Octava. 2013. Evaluasi Efektivitas Fungsi Satuan Pengawas Intern (SPI) Dalam Melaksanakan Audit Internal. Jurnal Akuntansi AKUNESA 1 (2).

Sawyer, Lawrence B, etal. 2005. Sawyer 's Internal Auditing; Audit Internal Sawyer. Jakarta: PT. Salemba Empat

Sirat, Mularia CJ. 2010. Risk Base Internal Audit (RBIA). Jurnal Auditor, Volume 3, No. 5, Juni 2010, Hlm. 5-15.

Tampubolon, R. 2005. Risk and system based Internal Auditing. Jakarta: Elex Media Komputindo.

Tawaf, Tjukria P. 1999. Audit Intern Bank. Jakarta: PT. Salemba Empat Yin, R. 2003. Qualitative research methods: Sage, Thousand Oaks, CA. 